I denne spalten presenteres tidligere publiserte artikler, mange av dem fra Tidsskriftet.

Artiklene er utvalgt og blir introdusert av Ole Didrik Lærum.

\title{
Hvem er forfatter?
}

Det er stas å være forfatter. Det er også utrolig kjekt å ha navnet sitt på en publikasjon. Hvis artikkelen er lang og komplisert, ser det dessuten ganske imponerende ut.

Gjennom atskillige tiår har den medisinske vitenskapen vært preget av mange menneskers samarbeid, og det har medført at forfatterlisten kan bli nokså lang. Men det er ikke alltid at de som står på forfatterlisten, har ytt noe særlig. Tvertimot - de kan ha sneket seg innpå med listige midler for å få navnet sitt på trykk. Diverse ubehagelige opplevelser fra internasjonalt forskningsarbeid medførte at jeg skrev en spøkefull artikkel om dette problemet i 1982. Her ble alle de vanlige metodene for å bli medforfatter omtalt i detalj. Her finnes det både varianter av tilsynelatende aktverdige måter og sleipe triks - vel å merke hvis man selv ønsker å bli medforfatter. Imidlertid finnes også en annen variant, og det er hvordan man skal bli kvitt potensielle medforfattere. Er man så heldig å sitte på vitenskapelige data, er det kjekkest å slippe å dele æren med hærskare av andre personer. Så kan strategien velges etter hvilken posisjon man befinner seg i, det vil si om noen andre skal holdes ute eller om en selv skal komme inn.

Artikkelen min fikk et fint oppsett, men likevel ble den ikke noe vellykket. Den falt pladask til jorden. Kollegene syntes at dette var slett ikke morsomt. Noe slikt skulle man ikke spøke med. Eneste unntaket var min gode venn, professor Ansgar Torvik i Oslo, en internasjonalt kjent forsker innen nevropatologi. Han ba om å få se manuskriptet på forhånd. Etter noen dager kom svaret: «Kjære Ole Didrik. Takk for fint manuskript. Jeg vil gjerne være medforfatter!»

| 1980-årene kom de såkalte Vancouver-reglene for medforfatterskap i medisinske tidsskrifter. En rekke internasjonale redaktører hadde sett disse problemene og laget en arbeidsgruppe som utformet klare regler. De har siden vært retningsgivende. Likevel skjedde det etter hvert $\varnothing$ kende utglidning med praktisering av reglene. Etter en alvorlig uredelighetssak i Norge i 2004 tok journalisten Hans Wilhelm Steinfeld i etterkant opp spørsmålet om medforfattere, og artikkelen min ble gjenstand for et helt radioprogram. Heller ikke dette vakte noen reaksjon. Selve fusksaken førte imidlertid til at vi fikk en lov om etikk og redelighet i forskning, og bruk av Vancouverreglene ble innskjerpet.

Fortsatt er spørsmålet om hvem som skal være medforfattere et følsomt tema. Kunnskap om dette merkelige fenomenets sosiologi kan kanskje bidra til større åpenhet og at de internasjonale reglene blir praktisert på en betryggende måte. For det ligger alltid noen potensielle medforfattere på lur i buskene.

\section{Ole Didrik Lærum}

ole.laerum@gades.uib.no

Ole Didrik Lærum (f. 1940) er professor (adj.) ved Københavns Universitet og professor emeritus ved Universitetet i Bergen.

\section{Om medforfattere}

Ole Didrik Lærum, professor, dr med, Gades Institutt, Avdeling for Patologi, N-5016 Haukeland Sykehus, Bergen.

Nordisk Medicin 1982; 97: 320-323.

Noen forskere publiserer lite, og på visse forskningsinstitutter med stor arbeidsstokk kan det kanskje bare komme en eller to artikler i året. Andre forskere har en enorm produksjon; noen ligger helt oppe i 800-900 artikler. Ofte vet de ikke at de er med på en artikkel før de ser den på trykk. Når det gjelder antallet publikasjoner ligger de fleste forskere et sted midt i mellom disse to ytterpunktene.

Enkelte artikler har bare en forfatter, men de fleste har flere forfattere. På enkelte artikler er det en hel hærskare av forfatternavn som står under tittelen. Man kan lure på hvem i all verden som skjuler seg bak alle disse navnene. Kanskje er det institutt- sjefer, forskere av forskjellige slag, leger, teknikere, venner, forloveder, venninner og tilfeldig forbipasserende. Selvsagt må den som har gjort jobben stå på forfatterlisten. I løpet av siste ukes lesning av internasjonal faglitteratur fant jeg en rekke navn som i alle fall får norske ører til a sperre øynene opp. Der var både Flaks og Caputo, Potet og ikke minst Flaschenträger (flaskebærer).

I denne artikkelen skal jeg ta for meg de mange merkverdigheter som forekommer $\mathrm{i}$ forbindelse med forfatterlisten på vitenskapelige publikasjoner. Studiet av medforfatteres psykologi er i ferd med å bli en egen vitenskap; flere hittil ukjente lover blir nå avdekket.
Det ville imidlertid være trist om foreliggende artikkel bare skulle begrense seg til å beskrive og forklare en rekke pussige fenomener - såkalt merkverdighetsanalyse. Tvert imot må det handlingsvilje og aktive rådgjerder til, og dette handler den andre delen av artikkelen om. Hvis disse løsningene blir gjennomført i praksis, kan man forvente at noen hver etter dette kan komme til å bli medforfatter.

\section{De mange medforfattere}

Noe av det som holder den hardt arbeidende gransker oppe og hindrer ham i å miste motet, er tanken på at alle hans data skal publiseres i internasjonale tidsskrifter: Andre forskere skal finne at dette er epoke- 
gjørende. Ære og berømmelsen vil drysse ned over hans hode. Kanskje blir han invitert til å tale på kongresser, kjente forskerstørrelser kommer og hilser, og han blir opptatt blant de store gutta.

Skrivingen av en vitenskapelig artikkel krever langvarig og tungt arbeide. Så kommer sluttfasen. Alle data er bearbeidet og satt pent sammen i tabeller og kurver. Bildene er laget og montert på hvite ark. Råmanuskriptet er så å si ferdig skrevet og artikkelen begynner virkelig å se smukk ut. Forfatteren er sliten og medtatt etter langvarig arbeide. Han har ofte følt seg ensom mens alt dette har pågått, blant annet fordi ingen har villet hjelpe når han så mange ganger har bedt om det. Nå har han en følelse av at arbeidet har lyktes allikevel. Da er det at det store skjer: Plutselig får han en masse venner. Kolleger på instituttet kommer og klapper ham elskverdig på skulderen. Sjefen ber om å få lese gjennom manuskriptet. Han har tidligere ikke vist den ringeste interesse for prosjektet. Nå får forskeren endelig audiens og sjefen lyser av det elskverdigste smil. «Hm, dette er et meget smukt arbeide. Jeg kan i grunnen tenke meg å sende det inn for deg. Jeg kjenner redaktøren i det tidsskriftet du skal publisere i, og da går alt så mye lettere. Jeg bør vel også stå som medforfatter ... ». Etter navnet setter han en asterisk og nederst under dette tegnet står fotnoten: «To whom all correspondence should be addressed.»

Så kommer en kollega som pleide å komme inn og prate mens forsøksseriene foregikk på laboratoriet. Han sier: «Egentlig var jo jeg også med på dette, tenk på alle gangene jeg har hjulpet deg. Jeg bør vel stå som medforfatter». En annen har latt assistenten sin gi noen celler til forskeren, en har holdt i noen mus en gang det trengtes hjelp osvog plutselig står det en hel rad av navn på artikkelen. Kollegene begynner plutselig å tale i vi-form: «Vi har gjort en bra innsats, hva?» En ber om å få nevne noen av resultatene på en kongress, og dermed reiser han avgårde og legger det hele fram i sitt navn: «Abstract» fra kongressen føyes til som enda et nummer på litteraturlisten hans.

Slik kan det skje at det som til å begynne med var én manns arbeide framstår i tidsskriftet som et gruppearbeide av tallrike personer. Generelt sett kan det være et åpent spørsmål hvem som har gjort hva på en vitenskapelig publikasjon. Hvem har egentlig ansvaret for forskningsprosjektet og hvem kan innestå for det som er gjort?

\section{Den behendige eneforfatter}

Ikke alltid står det en horde av medforfattere på artikler. Den motsatte ytterlighet kan
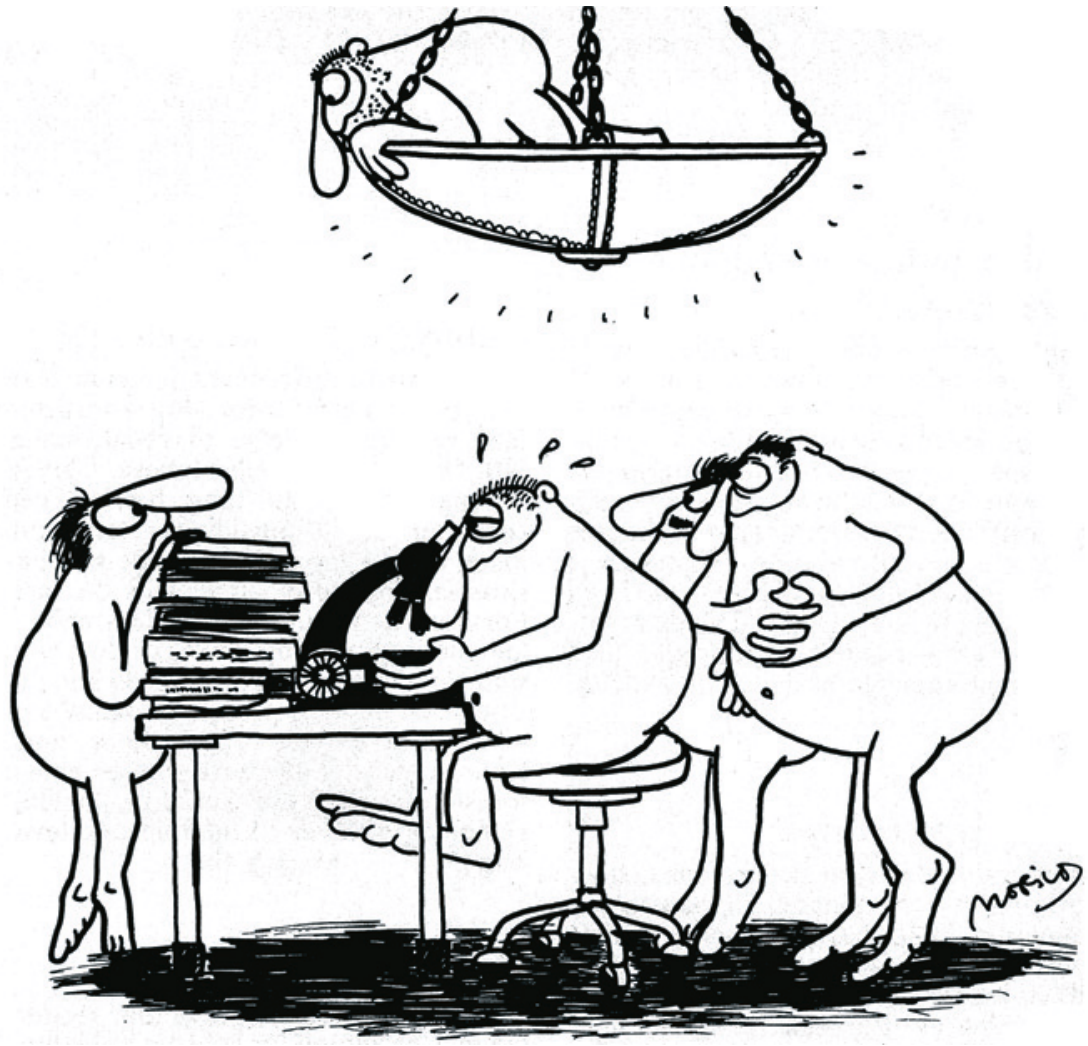

Mot slutten av et større vitenskapelig arbeide blir forskeren ofte gjenstand for en ustyrtelig grad av oppmerksomhet fra sine kolleger. Mon tro hva de er ute etter? Tegninger Inge Morild, Bergen

også forekomme. En forsker ber andre om hjelp og gir tydelig uttrykk for at han har det vondt. Han mobiliserer så mange han kan, alle løper i øst og vest for ham, henter saker, gjør forsøk, sprøyter mus, utfører spesialmetoder, skaffer utstyr til veie og kommer styrtende med både tall og kurver de har fått fram. Så tar forskeren dataene og er søkk borte. En tid seinere kommer et særtrykk inn døra: Der er alt publisert. Artikkelen har kun én forfatter, og de mange hjelperne blir bare såvidt nevnt under «acknowledgements».

Ved et langvarig samarbeidsprosjekt kan det og hende at den ene forskeren sitter med alle resultatene. Enkelte klarer da ikke å motstå fristelsen, men sender det raskt inn til publisering uten at de andre vet noe om det. Hvis det blir en pen artikkel, gjør det ikke så mye om visse ting er misforstått og galt skrevet hist og her fordi de andre kollegaene ikke fikk anledning til å se igjennom manuskriptet (1).

For endel år siden ble det offentliggjort en artikkel om bakterietallet $\mathrm{i}$ eggprodukter der «acknowledgement» var særdeles omfattende. Der sto det: «Vi takker dr JD og dr GS, Chicago, for de mikrobiologiske analysene og dr GRA, Philadelphia, for å ha overvåket innsamlingen av produktene, dr DHB og dr PWK, og endelig dr GWP og dr AB, California, for at vi fikk bruke deres data om henholdsvis antall salmonellae i kommersielt albumin og hele eggprøver.» Da kan man spørre: «Hva gjorde egentlig forfatterne?» (2).

Det kom også en ung fysikkstudent til et forskningsinstitutt et sted i utlandet og ba professoren om å få en oppgave han kunne bruke til et doktorarbeide. Professoren sa: «Jeg vet om et nokså aktuelt problem som vi kunne undersøke. Da kan De gjøre slik og slik. De skal bruke den og den metoden, og jeg skal vise Dem nøyaktig hvordan De gjør det.» Studenten fikk litteratur, han fikk en omfattende innføring i problemet som han ikke kjente til fra før. I tillegg fikk han bruke alt utstyret på professorens laboratorium og fikk mer og mindre hjelp til å gjøre undersøkelsen. Til slutt skrev han det hele sammen til en avhandling, og også her fikk han hjelp. Så viste det seg at han hadde gjort en epokegjørende oppdagelse. Ære, berømmelse og penger drysset ned over den unge fysiker. Professoren som sto bak det hele fikk imidlertid ingen kreditt, fuglen var fløyet avsted til en fet stilling, hadde tatt 
med seg data og protokoller, og etterlot sin sjef til glemselen.

Det hender også at data rett og slett blir stjålet, eller at en hel artikkel blir tatt og publisert $i$ andres navn $(3,4)$.

\section{Rekkefølgen av forfattere}

Ofte består en forskergruppe av en eldre erfaren forsker og flere yngre som skal hjelpes fram. Da pleier gjerne den yngste forskeren å få stå som førsteforfatter, da han trenger mest publikasjoner, mens senior står som sisteforfatter.

Hvis det er tvil om hvem som skal stå først, kan man alternere på forskjellige artikler. Tidligere var det gjerne slik at forfatterrekkefølgen skulle være alfabetisk. Enkelte forskere, hvor første bokstav i navnet er langt foran i alfabetet, holder fortsatt på dette (se tabell I (5)).

Forøvrig er det viktig å legge opp forsøksstrategien slik at man kommer langt framme, helst fremst på forfatterlisten. Her står en rekke metoder til rådighet. Den ene består i å gjemme forsøksprotokollen slik at de andre ikke får tilgang til dataene. Så kan man gjøre seg til venner med assistentene så man får dataene direkte fra dem. Kaffedrikking og småslarving er ofte et viktig strategisk våpen $i$ denne forbindelse. Man kan også doble forsøkene som en annen har gjort. Det er ikke noe vanskelig å reprodusere de data en annen har slitt seg fram til når man vet nøyaktig hva som skat finnes. En kan til og med gjøre det bedre enn den som opprinnelig gjorde arbeidet. Så kan den smarte gå til kollegaen og si: «Jeg har gjort mest. Du har valget mellom å være sisteforfatter eller ikke å være med i det hele tatt.» Hva skal man si til det?

Særlig ondartet er det når medarbeidere i vitenskapelige tidsskrifter får andres artikler til bedømmelse og stikker av med kaka. Metoden er ganske enkel. Man venter tre-fire måneder med å gi svar på om artikkelen er akseptabel, og jobber i mellomtiden som forrykt for å reprodusere dataene. Så er det bare å skrive. I beste fall kan man komme før konkurrenten, spesielt hvis en er lur nok til å refusere artikkelen som kom til bedømmelse. Da må nemlig forfatteren sende den til et annet tidsskrift hvor det kan ta like lang tid før han får den trykket. Det har flere steder i utlandet vært framsatt slike beskyldninger i tilfeller hvor konkurransen er særlig hard. Det hører med til historien at der hvor slikt har skjedd, blir den som har opphavsretten til ideen og prosjektet overhodet ikke sitert (3).

\section{Bytteleken}

Dette er en morsom og svært meritterende lek: Får jeg være med på dine artikler så skal du få være med på mine. Det er en fin metode til å få dobbelt så lang publikasjonsliste. Noen gjør det systematisk og kan derfor vedlegge kilovis av særtrykk når de søker om stillinger. Det kan også øke troverdigheten av et prosjekt hvis man får en kjent forsker til å stå som medforfatter og borge for (det kanskje tvilsomme) innholdet. Etterpå kan man om tale den berømte forskeren i familiære ordelag: «Han og jeg pleier gjerne å skrive våre artikler sammen».

\section{Kasuistikker}

Kasuistikker er ofte rike på medforfattere. Man får inntrykk av at legene har flokket seg rundt den stakkars pasienten, kastet seg over ham og undersøkt ham på kryss og tvers. Deretter har de løpt triumferende avgårde med dataene for å sende dem med ekspressfart til nærmeste tidsskrift. Det er meg en gåte hvordan opptil 10-15 leger skal være nødvendige for å undersøke og publisere en selsom sykdom hos en eneste pasient. Man kan spørre om den som har tatt pulsen på pasienten også skal få være med.

\section{Patentretter}

I forbindelse med forskning på såkalt rekombinant DNA er det nå flere forskere i USA som søker om patentrettigheter på de resultatene de har publisert. Det verserer flere rettsaker som kan få store konsekvenser hvis patentrettighetene blir innvilget. I så fall vil visse forskergrupper få enerett på bestemte typer forsøk og metoder. Det har til og med gått så langt at enkelte skriver artikler med henblikk på at de kan brukes til patentsøknad (6). Det har også vært stor strid om medforfatterskap i slike tilfelle. Dels har det vært viktig å få dyttet ut medforfattere, dels har medforfattere slåss for livet for å få være med på patentsøknaden. Når striden går om prestisje og penger er storsinn en sjelden egenskap.

\section{Mulige medforfatterproblem- løsninger}

I de store miljøer i utlandet med hard internasjonal konkurranse finnes det tallrike eksempler på strid i forbindelse med å få navnet sitt på forfatterlisten. Det vanlige er imidlertid at det går ordentlig og hederlig for seg, slik at de nevnte eksempler representerer unntak. Alle de involverte i et prosjekt pleier å se igjennom dataene i fellesskap og diskutere åpent hvordan det skal gjøres.

Kan vi med hånden på hjertet si at det alltid foregår slik? Og er ikke hele det nåværende systemet med forfattere i en bestemt rekkefølge både reaksjonært og udemokratisk? I sitt vesen favoriserer det de ressurssterke, og det gjelder spesielt førsteforfatterne. Det spørs om vi ikke nå bør gå inn for en demokratisering av medforfatteriet. Flere alternative løsninger ligger i grunnen helt oppe i dagen:

\section{Garantert minstemedforfatterskap i utdanningsstilling}

Prinsippet er at alle skal ha like retter i karrieresamfunnet. Enhver som er i utdanningsstilling skal være garantert å stå som medforfatter på minst tre publikasjoner i løpet av ansettelsesperioden, forutsatt 38 timers arbeidsuke og vanlige ferier. Ved overtid eller vakanser økes antallet tilsvarende. Tillitsverv i fagorganisasjoner honoreres med en ekstra publikasjon. Dermed vil de ansatte få en ganske annen samhørighet med den vitenskapelige aktivitet på avdelingen.

\section{Kjønnskvotering}

I enhver publikasjon skal halvparten av forfatterne være kvinner og halvparten menn. Hvilken halvpart som tilfaller hvilket kjønn fastsettes i det enkelte tilfelle i henhold til nærmere forskrifter utarbeidet av Forbruker- og Administrasjonsdepartementet. Dispensasjoner forutsettes kun gitt i unntakstilfelle. Avgjørelser kan ikke påklages med mindre de har gått i kvinnens disfavør.

\section{Loddtrekning}

En demokratisk løsning er å avgjøre både forfatternavnene og deres innbyrdes rekkefølge ved loddtrekning. Derved vil alle ha like muligheter til å gjøre karriere og få økt medinnflytelse. Disse reglene kan være særlig gunstige å anvende for dem som ikke er motivert for forskning. Etter å ha stått som medforfatter endel ganger er det gode muligheter for at de fleste vil bli motivert for vitenskapelig arbeide. Det forutsettes imidlertid at de som har vunnet ved loddtrekning ikke blir utsatt for diskriminering for eksempel i form av forlangende om at de skal skrive en del av artikkelen selv.

\section{Maksimalgrense for publikasjoner}

Her kunne man for eksempel sette en øvre grense på 50 artikler for enhver forsker. Forskere som har nådd grensen og ønsker å skrive mer, kan kun gjøre det ved å dementere et av sine tidligere arbeider. Det behøver ikke å by på problemer for noen hver kan av og til ønske å trekke artikler tilbake. Etter noen år vil man på denne måten oppnå at de fleste nærmer seg asymptotisk til denne magiske tallgrense, hvorved demokratiseringsprosessen i karrieresamfunnet blir framskyndet. Kvaliteten vil også stige (7).

Tabell 1 Svenska professorer och deras plats i alfabetet (6)

$\begin{array}{llll} & \begin{array}{l}\text { Profes- } \\ \text { sorer }\end{array} & \begin{array}{l}\text { Biträdande } \\ \text { professorer }\end{array} & \text { Studenter } \\ \text { A-N } & 76,3 \text { proc } & 71,6 \text { proc } & 66,8 \text { proc } \\ \text { 0-Ö } & 23,7 \text { proc } & 28,4 \text { proc } & 33,2 \text { proc } \\ \text { n } & 220 & 316 & \\ \end{array}$




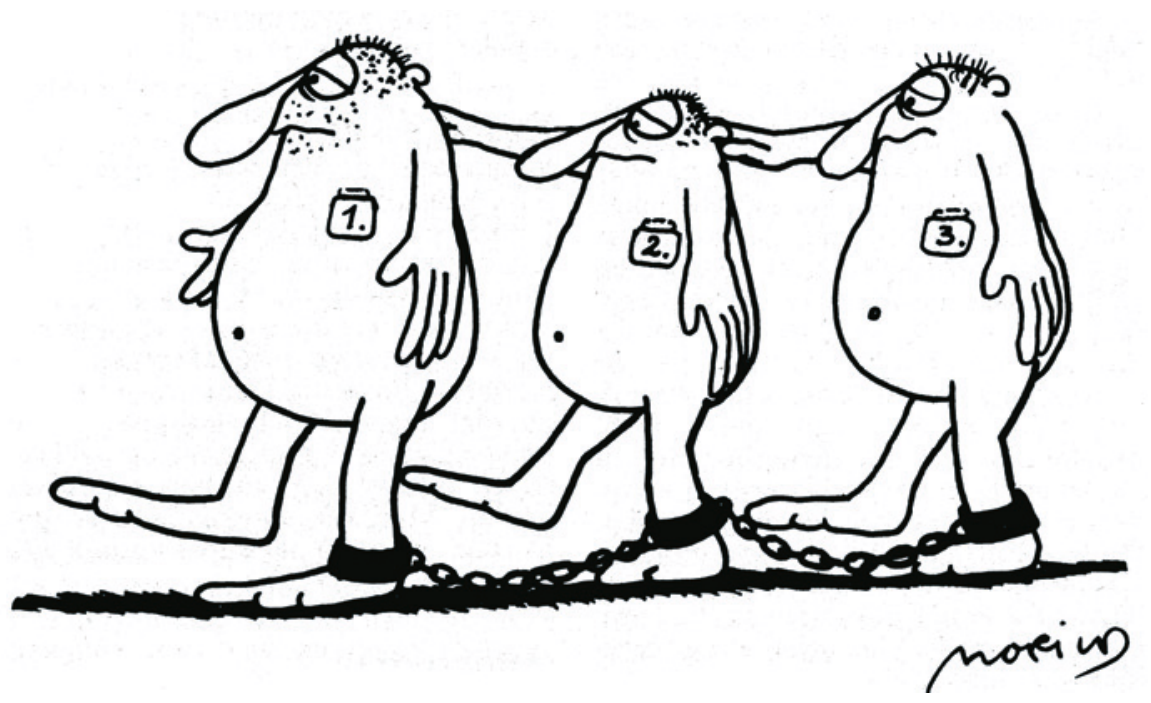

Samfunnet må nå kunne kreve en strengere kontroll av medforfatterne med bruk av virkemidler som har generalpreventiv effekt

\section{Anonyme publikasjoner (8)}

I stedet for forfatternavnene kunne man her sette $\mathrm{i}$ en fotnote: «Forfatterlisten fåes ved henvendelse til redaksjonen. NB! Diskret forsendelse loves». Derved vil man slippe all tung bæring ved søknader om toppstillinger, ettersom ingen lenger kan bevise hva de selv har skrevet. Her lurer imidlertid en fare. Forskere kan bruke hverandres anonyme publikasjoner og vedlegge dem som sine egne ved søknader. Derved kan det skje at en middels professorsøknad kan komme til å veie opptil flere tonn. Kanskje var det da bedre som en annen foreslo å forby vitenskapelige publikasjoner og gå over til muntlig overlevering (9).

\section{Pasienten som forfatter}

På kasuistikker er det mye mer rettferdig hvis pasienten får stå som hovedforfatter. Han har gjennomgått både sykdommen og alle de vonde undersøkelsene, så hvorfor skal ikke han ha noe igjen for det. Egentlig har pasienten ytt mye mer enn dem som målte blodtrykket og kikket ham i øyne, hals og nese, trykket ham på magen og så «hmm». Dessuten blir kasuistikker svært lite lest. For pasienten vil imidlertid en slik artikkel ha meget stor interesse; han kan la den gå i arv til sine etterkommere som et kostelig slektsdokument der arvingene får vite om stamfarens besynderlige helseproblemer. På store pasientmateriale, for eksempel der hvor mer enn 100 er blitt undersøkt, er dette selvsagt ikke gjennomførlig. Det samme gjelder hvis undersøkelsen er gjort på rotter og kaniner.

Forfatteren som egen medforfatter Egentlig er nåværende ordning svært urimelig. Dersom man har slitt og skrevet en artikkel selv, teller det som én publikasjon. Det samme gjør det hvis man står som medforfatter på andres publikasjoner uten å ha ytt noe som helst. Stort sett blir bare tallet på publikasjoner, eller antall kilo med papir vurdert ved ansettelse. Jeg har derfor den glede å presentere en ny og epokegjørende metode til gratis utdeling blant verdig trengende. Hvorfor ikke ta seg selv som medforfatter? Artikkelen teller først en gang fordi man er hovedforfatter, dernest fordi man er annenforfatter, og for tredje gang fordi man er tredjeforfatter. For at det ikke skal bli så lett gjennomskuelig, kan man variere navnet sitt litt for hver gang. Hvis man er så heldig å ha flere fornavn, slik som jeg, kan man alternere mellom å bruke det ene eller det andre fornavnet.

\section{Medforfatterskap via kjedebrev}

Dette er en nokså sleip metode, men ikke desto mindre særdeles effektiv for den som ønsker å gjøre rask karriere. Man sender ut et kjedebrev til vitenskapelige kollegaer, fortrinnsvis av den produktive sorten.

Listen på tre navn skal de ta som medforfattere på sine neste tre publikasjoner. Så føyer de til sine egne navn og hver sender det videre til tre andre kolleger med samme oppfordring. På kort tid kan man derved komme opp i en ustyrtelig lang publikasjonsliste. Ved søknader om toppstillinger vil man bli berømmet for en stor og særdeles allsidig vitenskapelig produksjon.

\section{Forskningsoppgave}

Det framgår med all tydelighet at medforfatteriet har innebygget en rekke skjevheter i sitt samfunnsmessige og miljø-ressursori- enterte perspektiv. Samtidig er fenomenet spennende, har rike fasetter og overraskende psykologiske trekk. Hvorfor har ikke dette vært forsket på, og hvorfor har ikke noen studert medforfatternes psykopatologi? Kanskje er det fordi alle de som kunne tenkes å være kvalifisert til slik forskning selv er residiverende medforfattere, ja kanskje mer enn de fleste.

Uansett psykologiske eiendommeligheter må samfunnet nå kunne kreve en økt styring av medforfatterne. En forfatterdemokratisering bør innføres ved lov for å hindre at noen få aktive skribenter skal stikke av med hele den vitenskapelige og litterære produksjon, mens andre må leve et langt liv uten å se sitt eget navn på trykk.

Kanskje vil vi en gang komme så langt at vår neste ikke bare angår oss som medmenneske, men også like mye som medforfatter. Vårt menneskelige fellesskap vil derfor få tilført en ny og epokegjørende dimensjon. Derfor må det være klinkende klart at de målsetninger og grunnleggende prinsipper som i denne sammenheng kommer på tale ikke bare skal integreres i samfunnet som helhet, men også like mye i relasjon til den utviklingsprosess i de sosioøkonomiske faktorer som har funnet sted i de seinere år og som har gitt en allmennpreventiv effekt og trygg forankring i de miljø- og ressursorienterte problemstillinger som på sikt får sitt mest demokratiske uttrykk på en adekvat og framtidsrettet måte.

Litteratur

1. Ogg CS, Cameron JS. Authorship of letter on routine venography in the nephrotic syndrome. Lancet 1980; ii: 321.

2. Garibaldi JA, Lineweaver H, ljichi K. Number of Salmonellae in commercially broken-egg before pasteurization. Poultry Science 1969; 48 1098-1101.

3. Joyce c. When the cheating has to stop. New Scientist 1981; 91: 68-9

4. Minerva: News and notes. Br Med J 1982; 284: 670.

5. Rossner S. Varfor blir just Aabel professor? Läkartidningen 1978; 75: 2918.

6. Dickson D. Inventorship dispute stalls DNA patent application. Nature 1980; 284: 388.

7. Durack DT. The weight of medical knowledge. New Engl J Med 1978; 298: 773-5.

8. Garfield E. Anonymous publications by 1984. Curr Cont 1976; 26: 5-7.

9. Anderson EC, Arnold JB, Emiliani C, Johnston WH, Miller RL, Suess HE, Telegdi VL. Back to the homeric traditi-on. Amer Sci 1955; 43: 177-9. 